\title{
Old Enzyme, New Role: The $\beta$-Glucosidase BglC of Streptomyces scabiei Interferes with the Plant Defense Mechanism by Hydrolyzing Scopolin
}

\author{
Benoit Deflandre (D) and Sébastien Rigali *(D) \\ InBioS-Center for Protein Engineering, Institut de Chimie B6a, University of Liège, B-4000 Liège, Belgium; \\ Benoit.Deflandre@uliege.be \\ * Correspondence: srigali@uliege.be
}

check for updates

Citation: Deflandre, B.; Rigali, S. Old Enzyme, New Role: The $\beta$-Glucosidase BglC of Streptomyces scabiei Interferes with the Plant Defense Mechanism by Hydrolyzing Scopolin. Biophysica 2022, 2, 1-7. https://doi.org/ 10.3390/biophysica2010001

Academic Editor: Javier Sancho

Received: 19 November 2021

Accepted: 20 December 2021

Published: 22 December 2021

Publisher's Note: MDPI stays neutral with regard to jurisdictional claims in published maps and institutional affiliations.

Copyright: () 2021 by the authors Licensee MDPI, Basel, Switzerland. This article is an open access article distributed under the terms and conditions of the Creative Commons Attribution (CC BY) license (https:// creativecommons.org/licenses/by/ $4.0 /)$.

\begin{abstract}
The beta-glucosidase BglC fulfills multiple functions in both primary metabolism and induction of pathogenicity of Streptomyces scabiei, the causative agent of common scab in root and tuber crops. Indeed, this enzyme hydrolyzes cellobiose and cellotriose to feed glycolysis with glucose directly and modifies the intracellular concentration of these cello-oligosaccharides, which are the virulence elicitors. The inactivation of $b g l C$ led to unexpected phenotypes such as the constitutive overproduction of thaxtomin A, the main virulence determinant of S. scabiei. In this work, we reveal a new target substrate of BglC, the phytoalexin scopolin. Removal of the glucose moiety of scopolin generates scopoletin, a potent inhibitor of thaxtomin A production. The hydrolysis of scopolin by BglC displayed substrate inhibition kinetics, which contrasts with the typical Michaelis-Menten saturation curve previously observed for the degradation of its natural substrate cellobiose. Our work, therefore, reveals that $\mathrm{BglC}$ targets both cello-oligosaccharide elicitors emanating from the hosts of S. scabiei, and the scopolin phytoalexin generated by the host defense mechanisms, thereby occupying a key position to fine-tune the production of the main virulence determinant thaxtomin A.
\end{abstract}

Keywords: common scab disease; beta-glucosidase; plant defense mechanism; virulence; pathogenicity; scopolin and scopoletin

\section{Introduction}

Common scab disease in root and tuber crops is caused by a dozen bacterial strains belonging to the Gram-positive Streptomyces genus, with strain Streptomyces scabiei (syn. S. scabies) as the model species. The major virulence determinants are 4-nitroindol-3-ylcontaining 2,5-dioxopiperazines called thaxtomins, which are potent cellulose synthesis inhibitors in higher plants [1]. Thaxtomin A is the most abundant toxin, and its biosynthesis, together with many other specialized metabolites that compose the "virulome" of $S$. scabiei [2-7], is triggered by cello-oligosaccharides, with cellotriose being the main elicitor emanating from the plant hosts [8-10]. Cellotriose is imported by the ABC-type transporter CebEFG-MsiK [8], and, once inside the cytoplasm, it prevents, together with cellobiose generated by cellotriose hydrolysis (see below), DNA-binding of the transcriptional repressor CebR, allowing the expression of the thaxtomin regulatory and biosynthetic genes [11,12].

One gene/protein intimately linked to the other players involved in the perception and transport of cello-oligosaccharides suggests that our current understanding of the virulence signaling pathway is partial. The piece that renders the jigsaw more complicated than initially thought is the beta-glucosidase BglC, whose primary function is to feed glycolysis with glucose released from the hydrolysis of cellotriose and cellobiose [13] (Figure 1, role (1)). Hence, it is expected that complete degradation of cellotriose and cellobiose into glucose by BglC prevents S. scabiei from accumulating the elicitors of the virulome and, as a consequence, behaves like a saprophyte. How BglC manages to control the intracellular concentration of cello-oligosaccharides for determining the proper timing of the pivotal 
switch from the saprophytic to the pathogenic lifestyles is currently unknown (Figure 1, role (2)). The deletion of $b g l C$ led to an unpredicted phenotype where $S$. scabiei (strain $\Delta b g l C)$ constitutively produced the thaxtomin phytotoxins in culture conditions free of cello-oligosaccharides and displaying a hypervirulent phenotype [13]. This unexpected cello-oligosaccharide-independent overproduction of thaxtomin A in strain $\triangle b g l C$ suggests that in the wild-type strain S. scabiei 87-22, BglC must repress a yet unknown alternative path to pathogenicity (Figure 1, role (3). Finally, we discovered that the primary function of $\mathrm{gglC} / \mathrm{BglC}$, i.e., the utilization of cello-oligosaccharides, is safeguarded by a mechanism of genetic compensation that awakens the expression of alternative beta-glucosidases upon perceiving the loss of $\mathrm{bglC}$ [14]. When BglC is active, the transcription of these alternative beta-glucosidases is kept to a minimal level and is not induced by cello-oligosaccharides (Figure 1, role (4).

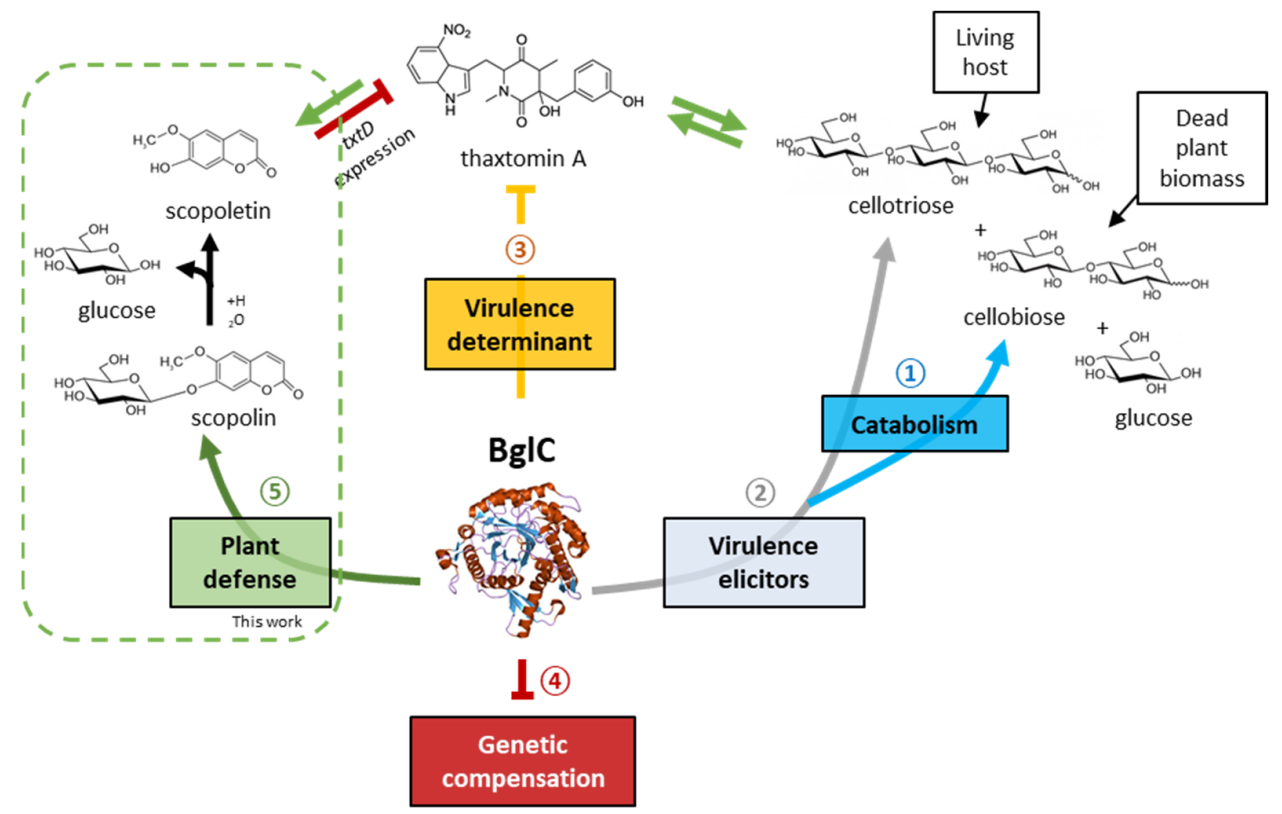

Figure 1. The five biological functions associated with BglC of S. scabiei 87-22. (1) The primary function of $\mathrm{BglC}$ is to hydrolyze cellobiose, the main product resulting from the degradation of cellulose from decaying plant material, and cellotriose to directly feed glycolysis with glucose [13]; (2) BglC degrades cellotriose as virulence elicitor released from living hosts [9] and therefore finetunes the strength of thaxtomin production, a crucial determinant for the onset of the pathogenic lifestyle of S. scabiei; (3) BglC represses the production of thaxtomin A, the main virulence determinant of S. scabiei, by a yet unknown cello-oligosaccharide-independent mechanism [13]; (4) The betaglucosidase activity of $\mathrm{BglC}$ is safeguarded by a mechanism of genetic compensation that represses the expression/production of alternative beta-glucosidases [14]; (5) In this work, we showed that $\mathrm{BglC}$ also hydrolyzes the phytoalexin scopolin into scopoletin, a strong inhibitor of thaxtomin A produced by plants colonized by S. scabiei [15].

Because of its multiple roles as well as the unexpected phenotypes and physiological responses of the $\mathrm{bglC}$ null mutant, $\mathrm{BglC}$ is an untapped source to provide crucial information for properly understanding the lifestyle of S. scabiei. In this work, we unveil a fifth role for $\mathrm{BglC}$. This beta-glucosidase can also hydrolyze the phytoalexin scopolin into scopoletin, the latter being a strong thaxtomin A inhibitor which is produced as a defense mechanism by plants upon colonization by S. scabiei.

\section{Materials and Methods}

\subsection{Heterologous Production of $\mathrm{His}_{6}$-Tagged Proteins and Purification}

BglC of S. scabiei 87-22 with a six-histidine tag fused to the N-terminus part of the protein $\left(\mathrm{His}_{6}-\mathrm{BglC}\right)$ was produced in Escherichia coli BL21(DE3) Rosetta ${ }^{\mathrm{TM}}$ and purified by 
nickel affinity chromatography as described in $[13,14]$. The pure protein was stored and used in HEPES buffer (50 mM, pH 7.5).

\subsection{TLC for Hydrolysis of Carbohydrates}

Semi-quantitative substrate degradation was assessed by thin-layer chromatography (TLC). Reactions were carried out with $\mathrm{His}_{6}-\mathrm{BglC}(1 \mu \mathrm{M})$ and the substrates $(5 \mathrm{mM})$ in HEPES $50 \mathrm{mM} \mathrm{pH} 7.5$ at $40{ }^{\circ} \mathrm{C}$ for $10 \mathrm{~min}$. At the end of the reaction, the mixture was incubated for $5 \mathrm{~min}$ in a boiling water bath to inactivate the enzyme. 1- $\mu \mathrm{L}$ samples of the inactivated reaction mixtures were spotted next to undigested standards on aluminumbacked TLC plates (Silica gel Matrix, Sigma-Aldrich) and thoroughly dried. The protocol, adapted from [16], consisted of eluting the loaded TLC plate in a TLC chamber filled with an elution buffer (Chloroform-Methanol-Acetic acid-Water (50:50:15:5 (v/v)). After air-drying the eluted plate, sulfuric acid (5\%) in ethanol was sprayed onto the TLC plate, and the excess liquid was drained. The visualization of the spots was finally conducted by heating the TLC plate.

\subsection{Determination of Kinetic Parameters for $\mathrm{His}_{6}-\mathrm{BglC}$}

The hydrolysis of scopolin was evaluated by glucose quantification using the DGlucose HK Assay Kit (Megazyme) following the microplate procedure. $\mathrm{His}_{6}$-BglC was

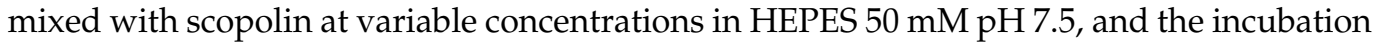
was conducted at $40{ }^{\circ} \mathrm{C}$ for $4 \mathrm{~min}$. The reaction was terminated by a 5 min incubation in a boiling water bath. At least 10 different concentrations of scopoletin-if possible distributed around the $\mathrm{K}_{\mathrm{m}}$ value-were tested in triplicate to estimate initial velocity values. The obtained data-initial velocity $\left(\mathrm{V}_{\mathrm{i}}, \mathrm{mM} / \mathrm{min}\right)$ in function of scopolin concentration ([S], $\left.\mathrm{mM}\right)$ were fitted to the Substrate inhibition equation $\mathrm{V}_{\mathrm{i}}=\left(\mathrm{V}_{\max }{ }^{*}[\mathrm{~S}]\right) /\left(\mathrm{K}_{\mathrm{m}}+[\mathrm{S}]^{*}\left(1+[\mathrm{S}] / \mathrm{K}_{\mathrm{i}}\right)\right)$ using the GraphPad Prism (version 9.2.0) software.

\section{Results}

Due to the multiple functions fulfilled by BglC that cannot be explained by a single activity on its natural substrates, cellobiose and cellotriose, we investigated if this betaglucosidase would target other carbohydrates with a terminal glucose attached by a $\beta-1,4$ linkage. The KEGG pathway [17] suggested a role for BglC of S. scabiei 87-22 in cyanoamino acid metabolism (https://www.genome.jp/kegg-bin/show_pathway?scb00460+SCAB_ 57721; accessed on 12 October 2021). Two cyanogenic glucosides were tested as possible targets of BglC, amygdalin and linamarin. The glycone moiety of amygdalin is the disaccharide gentiobiose (also called amygdalose), and its aglycone part is mandelonitrile, the cyanohydrin of benzaldehyde; linamarin is a glucoside of acetone cyanohydrin. According to the hypervirulent phenotype of the $b g l C$ null mutant [13], the scopolin heteroside was additionally selected as a possible substrate of BglC. Scopolin is the glucoconjugate of scopoletin, a phytoalexin produced by plants under colonization by S. scabiei or under application of pure thaxtomin A. The production of scopoletin and its glucoconjugate (e.g., scopolin) was observed in infected Arabidopsis thaliana seedlings, tobacco leaves [15], and potato tuber tissue $[18,19]$. Lerat and colleagues observed that, during $S$. scabiei infection, the production of scopoletin was responsive to thaxtomin A and that this compound acts as a powerful inhibitor of the expression of $t x t D$, consequently limiting thaxtomin biosynthesis [15].

Semi-quantitative substrate degradation was first assessed by thin-layer chromatography (TLC) where amygdalin and its glucoside moiety gentiobiose, linamarin, and scopolin $(5 \mathrm{mM})$ were incubated with $1 \mu \mathrm{M}$ pure six-histidine tagged BglC $\left(\mathrm{His}_{6}-\mathrm{BglC}\right)$ (see the Materials and Methods section for detailed protocols). Cellobiose was included in these degradation assays as a positive control to assess the correct activity of pure $\mathrm{His}_{6}-\mathrm{BglC}$. Reaction samples were spotted on TLC plates and migrated in an elution chamber to separate the glucose moiety (or possibly the gentiobiose moiety in the case of amygdalin) from the rest of the substrate. As shown in Figure 2, glucose was released from cellobiose 
when the disaccharide was incubated with $\mathrm{His}_{6}-\mathrm{BglC}$, thereby confirming that the pure beta-glucosidase was active. $\mathrm{His}_{6}-\mathrm{BglC}$ did not degrade $\mathrm{D}$-amygdalin nor gentiobiose, the glycone moiety of amygdalin. Similarly, glucose was not released from linamarin upon incubation with $\mathrm{His}_{6}$-BglC. In contrast, a clear spot with the same migration rate as glucose was observed when scopolin was incubated with $\mathrm{His}_{6}$-BglC.
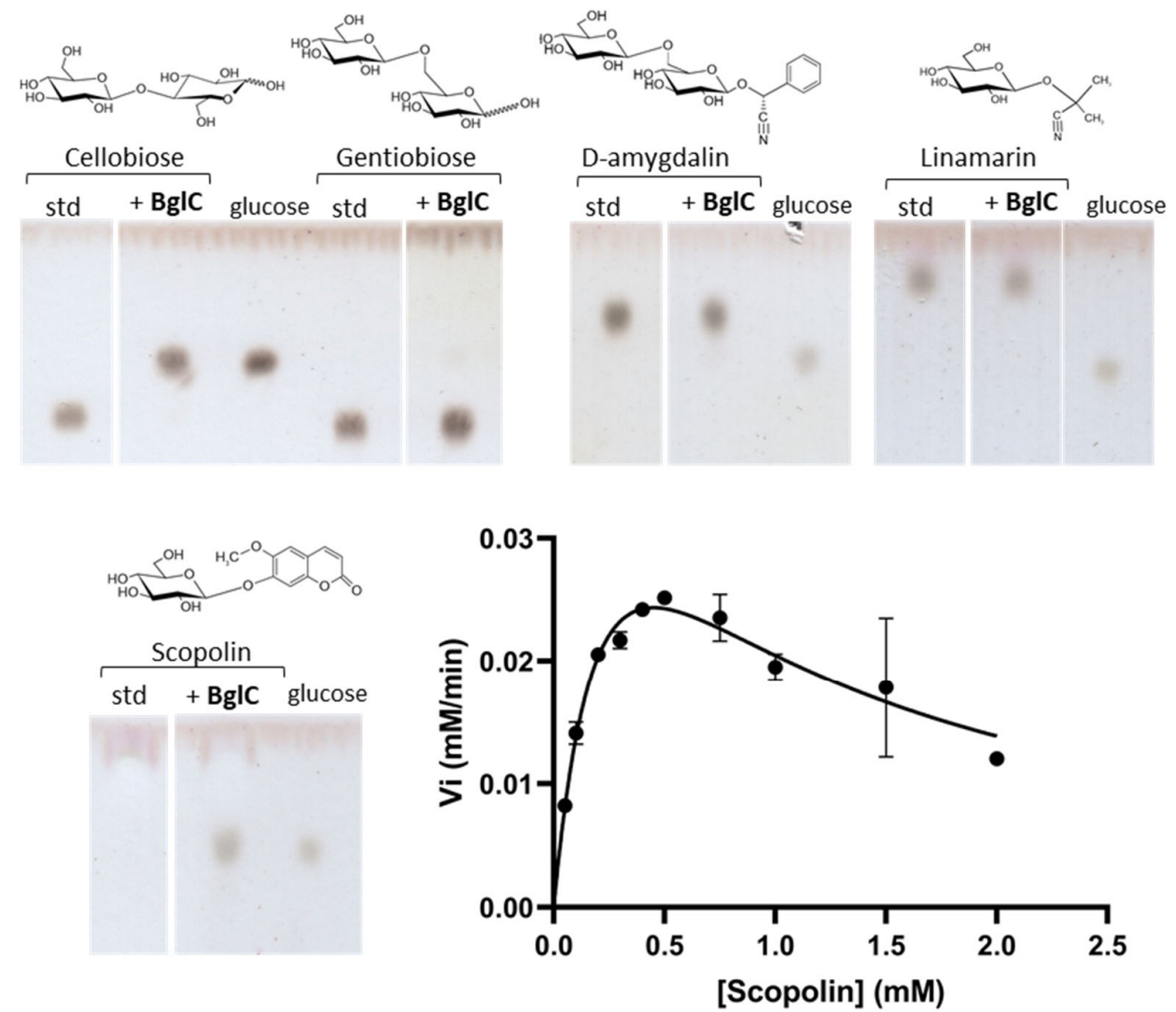

Figure 2. Beta-glucosidase activity of BglC on scopolin. Upper and bottom left panels: TLC plates revealing the release of glucose after incubation of a variety of substrates $(5 \mathrm{mM})$ with $\mathrm{His}_{6}$ - $\mathrm{BglC}$ $(1 \mu \mathrm{M})$ compared to the intact substrate (standard (std)). The respective chemical structures of the substrates are displayed above each name. Note that scopolin and its aglycone scopoletin both migrate almost at the same height as the solvent front, which makes it difficult to visualize these compounds. Bottom right panel: Plot of the initial velocity $\left(\mathrm{V}_{\mathrm{i}}, \mathrm{mM} / \mathrm{min}\right)$ estimated by the rate of glucose released by $\mathrm{His}_{6}$ - $\mathrm{BglC}$ as a function of scopolin concentrations (in $\mathrm{mM}$ ). Individual values were entered into the GraphPad Prism software (9.2.0), which fitted the data to the Substrate Inhibition model. Error bars display the standard deviation values determined for the $V_{i}$ for three replicates at each substrate concentration.

Following these preliminary enzymatic assays through TLC, the hydrolysis of scopolin by $\mathrm{His}_{6}-\mathrm{BglC}$ was further investigated by determining the kinetic parameters of the reaction. As deducted from the non-linear regression profile (Figure 2, bottom right panel), $\mathrm{His}_{6}$ - $\mathrm{BglC}$ is subjected to substrate inhibition when scopolin is provided at a concentration of $1 \mathrm{mM}$ or higher. The inhibitory constant $\left(\mathrm{K}_{\mathrm{i}}\right)$ for $\mathrm{His}_{6}-\mathrm{BglC}$ was calculated at $0.68 \mathrm{mM}$ as deducted using the equation $V_{i}=\left(V_{\max }{ }^{*}[\mathrm{~S}]\right) /\left(\mathrm{K}_{\mathrm{m}}+[\mathrm{S}]^{*}\left(1+[\mathrm{S}] / \mathrm{K}_{\mathrm{i}}\right)\right)$ proposed by the GraphPad Prism software (version 9.2.0). The $K_{m}$ (affinity of the enzyme for the substrate) and $k_{\text {cat }}$ (turnover of substrate molecules per second) values were $0.30 \mathrm{mM}(0.77 \mathrm{mM}$ for cellobiose), and $9.4 \mathrm{~s}^{-1}\left(6.7 \mathrm{~s}^{-1}\right.$ for cellobiose), respectively. 


\section{Discussion}

In this work, we revealed that the phytoalexin scopolin is a new substrate hydrolyzed by the beta-glucosidase $\mathrm{BglC}$, further expanding the crucial biological roles played by this enzyme in S. scabiei (Figure 1, role (5)). Although scopolin-hydrolyzing beta-glucosidases were previously identified in the roots of Arabidopsis [20], BglC of S. scabiei is the first example of a bacterial beta-glucosidase able to degrade this plant heteroside. By hydrolyzing the molecules (cellotriose and cellobiose) that activate thaxtomin production, as well as a molecule (scopolin) that generates an inhibitor of thaxtomin biosynthesis, $\mathrm{BglC}$ occupies a key position to fine-tune the production of the main virulence determinant of $S$. scabiei (Figure 3).

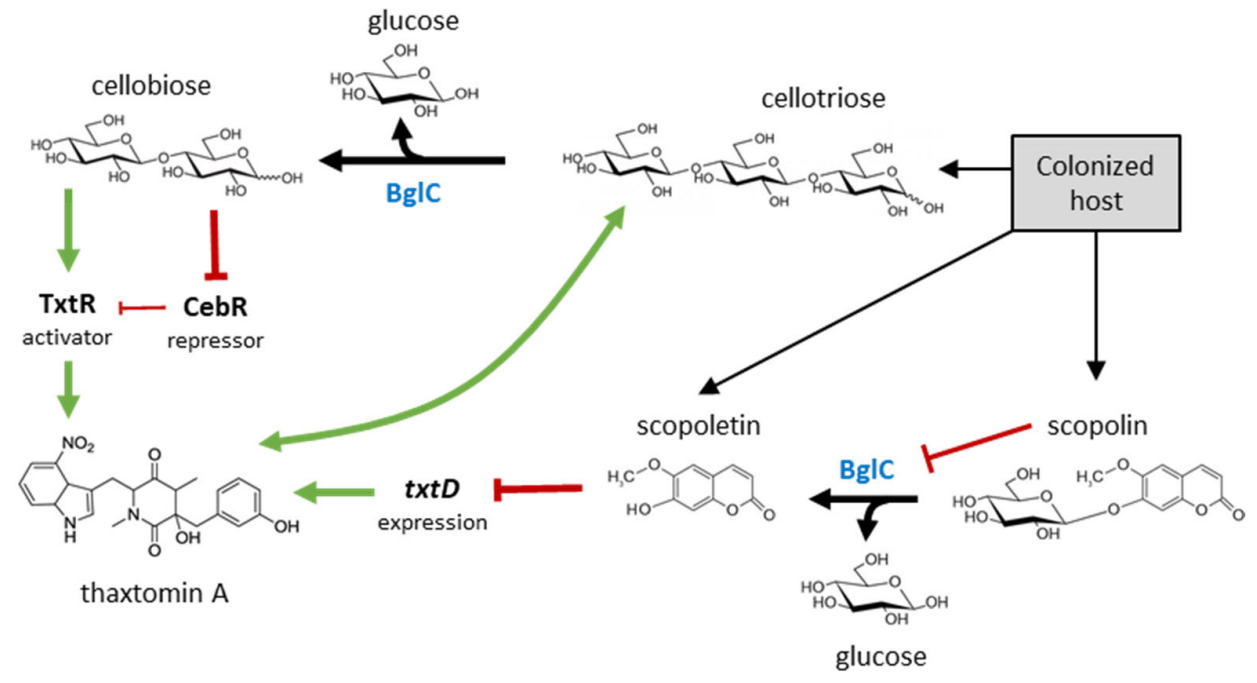

Figure 3. BglC-mediated fine-tuning of thaxtomin production in S. scabiei. Cellotriose emanating from expanding plant tissue triggers thaxtomin A production which in turn causes more release of cellotriose from the host [9]. Perception of thaxtomin A by the colonized host induces the production of the scopolin and scopoletin phytoalexins [15], the latter being a strong repressor of thaxtomin A production by reducing the expression of $t x t D$ (also called nos, scab31841) [15]. Hydrolysis of cellotriose by BglC generates cellobiose, the best allosteric effector of CebR-the repressor of the thaxtomin biosynthetic gene cluster-which also directly represses the expression of the thaxtomin pathway-specific activator TxtR [12]. High concentrations of scopolin would inhibit the activity of $\mathrm{BglC}$, resulting in (i) less accumulation of scopoletin (a thaxtomin A inhibitor) and (ii) limited degradation of cellotriose (the thaxtomin A inducer); both consequences are presumed to cause increased thaxtomin A production.

The kinetic values for the hydrolysis of cellobiose and scopolin are in the same order of magnitude. The major difference between the two substrates is that for scopolin, the activity of $\mathrm{BglC}$ is inhibited at high concentrations of substrate, whereas in the case of cello-oligosaccharides, $\mathrm{BglC}$ remains fully active at the highest concentration tested, and the kinetic analysis follows a classic Michaelis-Menten curve [13]. As many GH1-family beta-glucosidases are inhibited by their product, which would be glucose in the case of $\mathrm{BglC}$, it is tempting to interpret the enzymatic curve presented in Figure 2 as a result of product inhibition rather than substrate inhibition. However, the protocol used to generate our enzymatic data is the quantification of the glucose released and not the degradation of the substrate scopolin with increasing concentrations of glucose. Moreover, BglC of S. scabiei is one of the most glucose-resistant beta-glucosidase characterized so far [21]. In the proposed model presented in Figure 3, high concentrations of scopolin would inhibit the activity of $\mathrm{BglC}$, which would result in (i) less accumulation of scopoletin (a thaxtomin production inhibitor), and (ii) limited degradation of cellotriose (the thaxtomin production inducer). Both consequences are presumed to cause an increase in thaxtomin production. 
Finally, an important question that remains is how scopolin can reach the cytosol of the bacterium since BglC is intracellular. Streptomycetes possess a huge number of sugar transporters [22], but investigation of plant heteroside-specific importers has never been performed. However, the identification and characterization of an intracellular GH3 family beta-glucosidase (BcpE2, see [14] for its discovery) with high promiscuity for plant heterosides (scopolin included) strongly supports the existence of such transporters in these bacteria [23].

Author Contributions: Conceptualization, B.D. and S.R.; methodology, B.D.; validation, B.D. and S.R.; formal analysis, B.D. and S.R.; investigation, B.D.; resources, S.R.; writing-original draft preparation, B.D. and S.R.; writing-review and editing, B.D. and S.R.; visualization, S.R.; supervision, S.R.; project administration, S.R.; funding acquisition, S.R. All authors have read and agreed to the published version of the manuscript.

Funding: The work of B.D. was supported by an aspirant grant from the FNRS (grant 1.A618.18), and a FNRS grant "Crédit de recherche" (grant CDR/OL J.0158.21) to S.R. S.R. is a senior research associate of the FRS-FNRS (Brussels, Belgium).

Data Availability Statement: Not applicable.

Acknowledgments: We are very grateful to Isolde Francis and Nudzejma Stulanovic for the careful reading of the manuscript and molecule drawing.

Conflicts of Interest: The authors declare no conflict of interest. The funders had no role in the design of the study; in the collection, analyses, or interpretation of data; in the writing of the manuscript, or in the decision to publish the results.

\section{References}

1. Loria, R.; Bignell, D.R.D.; Moll, S.; Huguet-Tapia, J.C.; Joshi, M.V.; Johnson, E.G.; Seipke, R.F.; Gibson, D.M. Thaxtomin biosynthesis: The path to plant pathogenicity in the genus Streptomyces. Antonie Van Leeuwenhoek 2008, 94, 3-10. [CrossRef]

2. Liu, J.; Nothias, L.-F.; Dorrestein, P.C.; Tahlan, K.; Bignell, D.R.D. Genomic and metabolomic analysis of the potato common scab pathogen Streptomyces Scabiei. ACS Omega 2021, 6, 11474-11487. [CrossRef] [PubMed]

3. Li, Y.; Liu, J.; Díaz-Cruz, G.; Cheng, Z.; Bignell, D.R.D. Virulence mechanisms of plant-pathogenic Streptomyces species: An updated review. Microbiology 2019, 165, 1025-1040. [CrossRef]

4. Bignell, D.R.D.; Huguet-Tapia, J.C.; Joshi, M.V.; Pettis, G.S.; Loria, R. What does it take to be a plant pathogen: Genomic insights from Streptomyces species. Antonie Van Leeuwenhoek 2010, 98, 179-194. [CrossRef] [PubMed]

5. Deflandre, B.; Stulanovic, N.; Planckaert, S.; Anderssen, S.; Bonometti, B.; Karim, L.; Coppieters, W.; Devreese, B.; Rigali, S. The virulome of Streptomyces Scabiei in response to cello-oligosaccharide elicitors. bioarXiv 2021. [CrossRef]

6. Planckaert, S.; Deflandre, B.; de Vries, A.-M.; Ameye, M.; Martins, J.C.; Audenaert, K.; Rigali, S.; Devreese, B. Identification of novel rotihibin analogues in Streptomyces scabies, including discovery of its biosynthetic gene cluster. Microbiol Spectr. 2021, 9, e0057121. [CrossRef]

7. Planckaert, S.; Jourdan, S.; Francis, I.M.; Deflandre, B.; Rigali, S.; Devreese, B. Proteomic response to thaxtomin phytotoxin elicitor cellobiose and to deletion of cellulose utilization regulator CebR in Streptomyces scabies. J. Proteome Res. 2018, 17, $3837-3852$. [CrossRef] [PubMed]

8. Jourdan, S.; Francis, I.M.; Kim, M.J.; Salazar, J.J.C.; Planckaert, S.; Frère, J.-M.; Matagne, A.; Kerff, F.; Devreese, B.; Loria, R.; et al. The CebE/MsiK transporter is a doorway to the cello-oligosaccharide-mediated induction of Streptomyces scabies pathogenicity. Sci. Rep. 2016, 6, 27144. [CrossRef]

9. Johnson, E.G.; Joshi, M.V.; Gibson, D.M.; Loria, R. Cello-oligosaccharides released from host plants induce pathogenicity in scab-causing Streptomyces species. Physiol. Mol. Plant Pathol. 2007, 71, 18-25. [CrossRef]

10. Jourdan, S.; Francis, I.M.; Deflandre, B.; Loria, R.; Rigali, S. Tracking the subtle mutations driving host sensing by the plant pathogen Streptomyces scabies. mSphere 2017, 2, e00367-16. [CrossRef]

11. Francis, I.M.; Jourdan, S.; Fanara, S.; Loria, R.; Rigali, S. The cellobiose sensor CebR is the gatekeeper of Streptomyces scabies pathogenicity. mBio 2015, 6, e02018. [CrossRef] [PubMed]

12. Joshi, M.V.; Bignell, D.R.D.; Johnson, E.G.; Sparks, J.P.; Gibson, D.M.; Loria, R. The AraC/XylS regulator TxtR modulates thaxtomin biosynthesis and virulence in Streptomyces scabies. Mol. Microbiol. 2007, 66, 633-642. [CrossRef]

13. Jourdan, S.; Francis, I.M.; Deflandre, B.; Tenconi, E.; Riley, J.; Planckaert, S.; Tocquin, P.; Martinet, L.; Devreese, B.; Loria, R.; et al. Contribution of the $\beta$-glucosidase BglC to the onset of the pathogenic lifestyle of Streptomyces scabies. Mol. Plant Pathol. 2018, 19, 1480-1490. [CrossRef] [PubMed] 
14. Deflandre, B.; Thiébaut, N.; Planckaert, S.; Jourdan, S.; Anderssen, S.; Hanikenne, M.; Devreese, B.; Francis, I.; Rigali, S. Deletion of BglC triggers a genetic compensation response by awakening the expression of alternative beta-glucosidase. Biochim. Biophys. Acta Gene Regul. Mech. 2020, 1863, 194615. [CrossRef] [PubMed]

15. Lerat, S.; Babana, A.H.; El Oirdi, M.; El Hadrami, A.; Daayf, F.; Beaudoin, N.; Bouarab, K.; Beaulieu, C. Streptomyces scabiei and its toxin thaxtomin a induce scopoletin biosynthesis in tobacco and arabidopsis thaliana. Plant Cell Rep. 2009, 28, 1895-1903. [CrossRef]

16. Gao, J.; Wakarchuk, W. Characterization of five $\beta$-glycoside hydrolases from cellulomonas fimi ATCC 484. J. Bacteriol. 2014, 196, 4103-4110. [CrossRef] [PubMed]

17. Kanehisa, M. A Database for post-genome analysis. Trends Genet. 1997, 13, 375-376. [CrossRef]

18. Clarke, D.D. The accumulation of scopolin in potato tissue in response to infection. Physiol. Plant Pathol. 1973, 3, 347-358. [CrossRef]

19. Nolte, P.; Secor, G.A.; Gudmestad, N.C.; Henningson, P.J. Detection and identification of fluorescent compounds in potato tuber tissue with corky patch syndrome. Am. Potato J. 1993, 70, 649-666. [CrossRef]

20. Ahn, Y.O.; Shimizu, B.; Sakata, K.; Gantulga, D.; Zhou, Z.; Bevan, D.R.; Esen, A. Scopolin-hydrolyzing $\beta$-glucosidases in roots of arabidopsis. Plant Cell Physiol. 2010, 51, 132-143. [CrossRef]

21. Jourdan, S.; Rigali, S. Use of a Sugar Tolerant Beta-Glucosidase. U.S. Patent US20190330607A1, 31 October 2019.

22. Titgemeyer, F.; Bertram, R.; Schlicht, M.; van Wezel, G.P.; Rigali, S. Zuckertransport und C-regulation in antibiotikaproduzierenden streptomyceten. BIOspektrum 2005, 3, 5.

23. Deflandre, B. New Insights into the Enzymatic Properties and Metabolic Profile of the Phytopathogen Streptomyces scabiei. Ph.D. Thesis, Liège University, Liège, Belgium, 2021. 